\title{
Who Doesn't Want to be an Entrepreneur? The Role of Need for Closure in Forming Entrepreneurial Intentions of Polish Students
}

\author{
Aleksandra Wąsowska
}

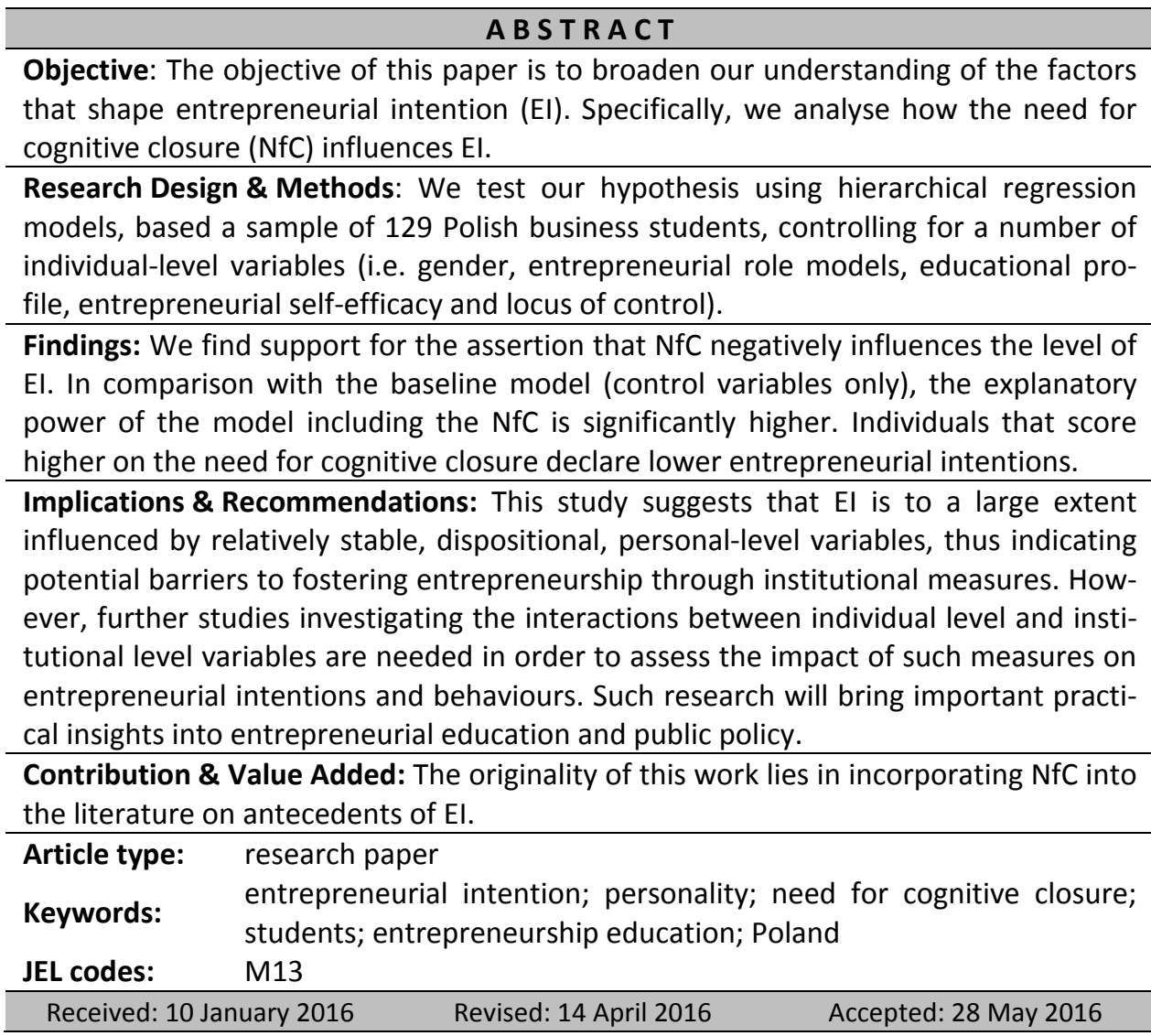

\section{Suggested citation:}

Wąsowska, A. (2016). Who Doesn't Want to be an Entrepreneur? The Role of Need for Closure in Forming Entrepreneurial Intention of Polish Students. Entrepreneurial Business and Economics Review, 4(3), 27-39, DOI: http://dx.doi.org/10.15678/EBER.2016.040303 


\section{INTRODUCTION}

One of the key elements of entrepreneurial activity is the process of forming the beliefs regarding the chances to succeed in a given venture (Schumpeter, 1911/1960). Therefore the fundamental questions asked in the entrepreneurship literature regard the ways in which these beliefs are formed and how they further translate into entrepreneurial behaviours (Shane \& Venkataraman, 2000). Most of entrepreneurship scholars agree that the entrepreneur is the key to understand this phenomenon. This is why entrepreneurship, at first being predominantly investigated by economists and sociologists, in the last 30 years has received much attention in psychological literature. Numerous studies in this stream of research investigate individual differences as determinants of entrepreneurial behaviours. However, the rich body of literature on psychological determinants of entrepreneurship has yielded ambiguous results and there are still important knowledge gaps, relating mostly to cognitive and motivational antecedents of entrepreneurial behaviours.

The aim of this paper is to contribute to the discussion on psychological antecedents of entrepreneurial intentions by focusing on the role of the need for cognitive closure. Based on a sample of 129 Polish business students, using hierarchical regression analysis, we investigate the need for cognitive closure $(\mathrm{NfC})$ as an antecedent of entrepreneurial intentions (EI), while controlling for entrepreneurial self-efficacy, locus of control, entrepreneurial role models, gender and educational profile. We find support for the notion that the need for cognitive closure is negatively related to entrepreneurial intent. To the best of our knowledge, this is one of the first studies incorporating the need for cognitive closure in explaining entrepreneurial intentions.

The article is structured as follows. We first present the literature review and develop our hypothesis. Next, we discuss the data collection procedure, sample, and operationalisation of variables. Then, we provide the results of the regression analysis. We also discuss both the theoretical and practical implications of our findings and the limitations of our study.

\section{LITERATURE REVIEW}

\section{Entrepreneurial Intention as a Domain of Studies}

Entrepreneurship has been defined as founding new organizations (Gartner, 1988), conducting entrepreneurial activity at ones' own sake (Zhao \& Seibert, 2006) or discovering, evaluating and exploiting opportunities (Shane \& Venkataraman, 2000). Global Entrepreneurship Monitor (GEM) defines entrepreneurship as "Any attempt at new business or new venture creation, such as self-employment, a new business organization, or the expansion of an existing business, by an individual, a team of individuals, or an established business" (Reynolds, Hay \& Camp, 1999, p. 3). All these definitions are behavioural, i.e. they relate to a specific behaviour or an intent to behave in a particular way (Rauch \& Frese, 2007).

Following the notion that "intention is the best single predictor of behaviour" (Fishbein \& Ajzen, 2010), a lot of research in the field of entrepreneurship has been focused on entrepreneurial intentions, defined as "the expressed behavioural intention to 
become an entrepreneur" (Zhao, Seibert \& Lumpkin, 2010, p. 383). The dominant theoretical frameworks in this stream of research are Ajzen's Theory of Planned Behaviour (Ajzen, 1991), originating from social psychology, and Shapero's Entrepreneurial Event Model (Shapero \& Sokol, 1984), originating from the entrepreneurship literature. These models to a great extent overlap (Kautonen, van Gelderen \& Fink, 2015) and have recently been integrated in a meta-analytical study by Schlaegel and Koenig (2014).

The rich body of literature on entrepreneurial intentions has been reviewed by Liñán and Fayolle (2015). Most influential papers in this field of research have been categorized into five groups. The first category covered papers discussing theoretical and methodological issues in IE research and testing the core models of IE. The second category covered papers focusing on personal-level variables, such as gender (Wilson, Kickul \& Marlino, 2007), family role models (Carr \& Sequeira, 2007), social capital (Liñán \& Santos, 2006) and personality traits (Segal, Borgia \& Schoenfeld, 2005). The third group of studies focused on the role of entrepreneurial education (Pittaway \& Cope, 2007). Papers falling into the fourth category investigated the role of context and institutions, covering multi-country samples (Engle et al., 2010). The last group of papers analysed intention-behaviour links, indicating that entrepreneurial intention is indeed a strong predictor of entrepreneurial behaviour (Kolvereid \& Isaksen, 2006).

Based on their extensive review, Fayolle and Liñán (2014) indicated the importance of individual-level variables, especially those grounded in cognitive psychology.

\section{Psychological Antecedents of Entrepreneurial Intentions}

The potential of integrating insights from psychological research to study economic phenomena has been signalled by the award of the Nobel Prize in economics to Daniel Kahneman for his work on judgment and decision-making under uncertainty. The cognitive approach, focusing on cognitive structures, cognitive styles, cognitive biases and heuristics and decision-making logic, has recently become the dominant perspective in entrepreneurship (Baron, 2004). This perspective focuses on how entrepreneurs "think". Busenitz and Barney (1997) pointed out that entrepreneurs use intuition more extensively than managers. They also manifest more "overconfidence" and representativeness biases and are less concerned about the facts.

Literature on entrepreneurial cognition overlaps to a certain extent with a broad stream of research focusing on the role of personality in entrepreneurship. Studies investigating the relationships between personality traits (e.g. risk preferences, achievement motivations) and entrepreneurship started in the 1960s (Litzinger, 1965; Wainer \& Rubin, 1969). However, by the late 1980s, this stream of literature had brought very few conclusive findings. As a result, numerous scholars raised serious doubts about the legitimacy of trait-based approach to study entrepreneurship. In his widely cited paper, Gartner (1988) stated: "I believe that attempt to answer the question 'Who is an entrepreneur?', which focuses on the trait and personality characteristics of entrepreneurs, will neither lead us to a definition of the entrepreneurs nor help us to understand the phenomenon of entrepreneurship" (p. 48).

Recently, interest in the role of personality in entrepreneurship re-emerges (Zhao, Seibert \& Lumpkin, 2010). This has been attributed to two phenomena (Kaczmarek \& Kaczmarek-Kurczak, 2012): the popularisation of meta-analysis as a technique allowing for analysing and integrating results from previous research, as well as the increasing 
legitimacy of the Five Factor model (FFM) as a coherent framework describing personality dimensions. This model includes five broad personality traits: emotional stability, extraversion, openness to experience, agreeableness, conscientiousness (Costa \& McCrae, 1992).

Zhao et al. (2010) have performed a meta-analysis of studies investigating the relationships between personality and entrepreneurial intentions and performance. They ground their study in career choice theory (Holland, 1997) and person-environment fit theory (Kristof, 1996). Both theories indicate that people choose career environment they fit and therefore, that vocational choices are to a certain extent reflection of personality. Based on the "task demands" and "work roles" related to the "job" of entrepreneur (i.e. goal achiever, relationship builder, risk taker, innovator), Zhao et al. (2010) formulate a set of hypotheses linking personality traits (i.e. Big Five and risk propensity) with entrepreneurial intentions and performance. Their meta-analysis indicated that emotional stability, extraversion, openness to experience, conscientiousness and risk propensity were positively related to entrepreneurial intentions. Moreover, all of these traits (with the exception of risk propensity) were positively related to entrepreneurial firm performance.

Rauch and Frese (2007) argue that broad traits, such as Big Five, are "distal and aggregated" and therefore they are not suited to predict specific behaviours, such as starting a business. They point at a number of specific personality traits, such as need for achievement, risk-taking, innovativeness, autonomy, locus of control, and self-efficacy, that are more directly linked to specific entrepreneurial behaviours. They call for the inclusion of other theoretical constructs in models explaining entrepreneurial behaviours, indicating the potential role of entrepreneurial cognition.

\section{Need for Cognitive Closure}

Recent contributions from cognitive psychology have brought a number of theoretical constructs that may be particularly relevant to explaining entrepreneurial intentions and behaviours. One of such constructs is the need for cognitive closure (Kruglanski, 1990).

Kruglanski $(1990$, p. 337) defines the need for cognitive closure as a desire for "an answer on a given topic, any answer, compared to confusion and ambiguity". NfC may be seen as a dimension of individual differences relating to individual's 'motivation with respect to information processing and judgement' (Webster \& Kruglanski, 1994, p. 1049). The term 'need' does not refer to the deficit, but to a motivated tendency (urgency tendency and permanence tendency) (Kruglanski \& Webster, 1996).

People that are characterised by high need for cognitive closure manifest a preference for structure, quick decision-making, predictability, rigidity of thought and low tolerance for ambiguity. Webster and Kruglanski (1994) propose that need for cognitive closure is a one-dimensional instrument with five facets: preference for order, preference for predictability, discomfort with ambiguity, closed-mindedness, decisiveness. Therefore, they conceptualise the NfC as a single latent variable, manifesting itself in various ways. Need for closure correlates positively with authoritarianism (characterized, by rigidity, conventionalism, and intolerance of those who violate conventional norms), intolerance of ambiguity, dogmatism (i.e. closed belief systems), impulsivity (i.e. tendency to be careless and impulsive, as opposed to cautious and reflective), and need for structure (i.e. desire to structure the environment); and negatively with cognitive com- 
plexity (i.e. capacity to interpret social behaviours in a multidimensional way), fear of invalidity (i.e. fear of making judgmental errors) and need for cognition (i.e. the extent to which one 'enjoys thinking') (Webster \& Kruglanski, 1994).

Tolerance for ambiguity have been found to influence entrepreneurial attitudes, intentions and behaviours, both in student and non-student samples. It was positively related to entrepreneurial intentions of Spanish (Espíritu-Olmos \& Sastre-Castillo, 2015) and Turkish (Gürol \& Atsan, 2006; Koh, 1996) students. Gupta and Govindarajan (1984) in their study of determinants of strategic business units (SBUs), found that tolerance for ambiguity contributed to effectiveness of strategy implementation in SBUs aimed at 'building' (i.e. increasing market share) and hampered the effectiveness of strategy implementation in SBUs aimed at 'harvesting' (i.e. maximizing short term profit and cash flow). Teoh and Foo (1997) in their study of entrepreneurs in small and medium-sized businesses in Singapore, found that tolerance for ambiguity moderated the relationship between role conflict and perceived performance, that is entrepreneurs with more tolerance for ambiguity were better positioned to 'neutralise' negative effect of role conflicts upon performance outcomes.

While the aforementioned studies focus on one facet of $\mathrm{NfC}$, that is tolerance for ambiguity, literature on the role of $\mathrm{NfC}$ in entrepreneurship, using the construct offered by Kruglanski (1990) is limited to very few studies. Schenkel, Matthews and Ford, (2009), using the Panel Study of Entrepreneurship Dynamics (PSED), found that NfC (measured with single-item proxies) was positively related with nascent entrepreneurial activity.

The exploratory study of Schenkel et al. (2009) enforces the idea that incorporating "cognitive factors rooted in the lay epistemic motivations of individuals" (p. 67) offer an opportunity to enhance the underlying nature of entrepreneurial behaviour. In discussing the limitations of their exploratory study, Schenkel et al. (2009) call for further research that would use the complete NfC scale grounded in psychology literature, employing a number of control variables.

The NfC construct is grounded in the social learning theory, assuming that individuals are motivated to avoid unpleasant stimulation and seek positive stimulation (Rotter, 1966). NfC involves two tendencies: urgency and permanence. Therefore, we follow Shenkel et al. (2009, p. 59) in arguing that NfC may pose a barrier to undertaking entrepreneurial activity, since "such situations will frustrate the desire to have order and predictability, prevent decisiveness, and produce feelings of discomfort resulting from ambiguity."

Entrepreneurship is inherently concerned with dealing with extreme uncertainty (Knight, 1921) and bringing about 'creative destruction' (Schumpeter, 1942/1976). Therefore, based on career choice theory (Holland, 1997) and person-environment fit theory (Kristof, 1996) we may expect that people who score high on the need for cognitive closure are less attracted to entrepreneurship and more inclined to pursue a more 'conventional' and predictable career path. We therefore formulate the following hypothesis:

H: Need for cognitive closure is negatively related to entrepreneurial intentions. 


\section{MATERIAL AND METHODS}

\section{Data Collection and Sample}

The questionnaire was addressed to 140 full-time MA students of the Faculty of Management, University of Warsaw, participating in the course of Strategic Management. The questionnaire (pen-and-paper, group study) was administered in December, 2014. Respondents who run their own businesses at the moment of the study $(n=8)$, as well as those which were incomplete $(n=3)$ were excluded from the analysis. The final sample comprised of 129 students (108 female and 21 male students), with average age of 22.6 $(S D=1.45)$. While the purposeful sampling has limitations, it yielded a sample that was to a large extent homogeneous in terms of age, current education profile, nationality, and place of residence.

\section{Measures}

The dependent variable, i.e. Entrepreneurial Intention was measured with a 4-item scale (EI) elaborated by Łaguna (2006a). Respondents were asked to assess, on a 5-point Likert scale, the degree to which they agree with the following statements: (1) 'I intend to start my own business', (2) 'I will use the opportunity to start own business', (3) 'I will try to start my own business', (4) 'I decided to start my own business'. The final result is computed as a mean of individual item scores. High scores in El scale correspond to high entrepreneurial intention.

Need for cognitive closure was measured with a shortened Need for Closure Scale, elaborated by Kruglanski, Webster and Klem (1993), adapted by Jaworski (1998). This scale comprises of 20 items (e.g. 'I think that having clear rules and order at work is essential for success', 'I don't like situations that are uncertain', 'I enjoy having a clear and structured mode of life'), assessed on a 6-point Likert scale. The final result is computed as a sum of individual item scores. High scores in this scale correspond to high need of cognitive closure.

Following the findings of previous studies indicating the role of gender (Wilson et al., 2007), education and family background (Wach, 2015) in forming entrepreneurial intentions, we control for gender (dichotomous variable), previous education (dichotomous variable: business versus non-business) and entrepreneurial role models (dichotomous variable assessed with a question 'My mother / my father owns or used to run her / his own business' and entrepreneurial self-efficacy).

Moreover, we control for two of the variables (namely: locus of control and entrepreneurial self-efficacy), originating from the psychological literature (Rotter, 1966; Bandura, 1997) and extensively used in studies investigating the link between personality and entrepreneurship.

The importance of locus of control to entrepreneurship stems from the fact that the belief in controlling one's future increases people's motivation to actively shape one's environment. Rauch and Frese (2007) conducted a meta-analysis of 20 studies and found a small, yet significant difference between owners and non-owners locus of control.

Locus of control (ELOC) has been measured with Internal-External Locus of Control scale elaborated by Rotter (1966). This is a 29-item scale, with 23 diagnostic items with dichotomous structure. Respondents choose between pairs of statements relating to 
everyday situations (e.g. 'When I make plans, I am almost certain that I can make them work.' versus: 'It is not always wise to plan too far ahead because many things turn out to be a matter of good or bad fortune anyhow'; 'Many of the unhappy things in people's lives are partly due to bad luck.', versus: 'People's misfortunes result from the mistakes they make.'; 'The idea that teachers are unfair to students is nonsense.', versus: 'Most students don't realize the extent to which their grades are influenced by accidental happenings.). High scores in I-E Scale correspond to external locus of control.

Entrepreneurial self-efficacy positively correlates with the propensity of becoming entrepreneur (Chen, Greene \& Crick, 1998) and achieving high (profits) in entrepreneurial activities (Markman, Balkin \& Baron, 2002). In also proved to be the key determinant of entrepreneurial intentions of Polish students (Wąsowska, 2016).

Entrepreneurial self-efficacy (ESE) was measured with a 21-item Entrepreneurial Self-Efficacy Scale, elaborated by Łaguna (2006a), based on Gatewood, Shaver \& Gartner, (1995). This scale is designed to 'measure perceived self-efficacy in carrying out tasks aimed at a new venture creation' (Łaguna, 2006a, p. 123). It has been originally validated on a group of participants of courses in entrepreneurship (aged 18-55) (taguna, 2006a) and subsequently used in studies on samples of unemployed (Łaguna, 2006b). Considering the fact that similar scales of entrepreneurial self-efficacy (Chen et al., 1998) have been used in student samples (Kaczmarek \& Kaczmarek-Kurczak, 2014), we believe that it is appropriate use this scale in our study. The scale has a 3-factor structure, corresponding to self-efficacy in three distinct narrow domains of entrepreneurial activity, i.e. (1) gathering marketing information, (2) managing financial and legal matters, and (3) setting up business operations. Respondents assess their efficacy beliefs on a 100-point scale, from 0 ('cannot do') to 100 ('highly certain can do'). The final result is computed as a mean of individual item scores. High scores in this scale correspond to high entrepreneurial self-efficacy. Correlation matrix and descriptive statistics are presented in table 1.

Table 1. Correlations and descriptive statistics

\begin{tabular}{|l|c|c|c|c|}
\cline { 2 - 5 } \multicolumn{2}{c|}{} & EI & ESE & NfC \\
\hline \multicolumn{5}{c|}{ r-Pearson correlations } \\
\hline EI & 1 & $0.326^{* *}$ & $-0.234^{* *}$ & -0.310 \\
\hline ESE & $0.326^{* *}$ & 1 & -0.133 & -0.171 \\
\hline NfC & $-0.234^{* *}$ & -0.133 & 1 & $0.21^{*}$ \\
\hline ELOC & - & - & - & 1 \\
\hline \multicolumn{5}{|c|}{ Descriptive statistics } \\
\hline Mean & 12.868 & 65.108 & 87.171 & 13.783 \\
\hline SD & 3.904 & 10.602 & 12.010 & 3.915 \\
\hline Minimum & 4.000 & 36.190 & 41.000 & 2.000 \\
\hline Maximum & 20.000 & 87.143 & 115.000 & 22.000 \\
\hline
\end{tabular}

Significant codes: $p<0.001 ; * * p<0.01 ;{ }^{*} p<0.05$

Source: own calculations in SPSS.

\section{RESULTS AND DISCUSSION}

A hierarchical regression analysis was performed to test the research hypothesis. We first run the baseline model (Model 1, Table 2), comprised of control variables only (respondent's gender, education profile, entrepreneurial role models, self-efficacy and 
locus of control). In the full model (Model 2, Table 2) we add the main tested variable, i.e. need for cognitive closure. We also examined potential multi-colinearity problems by calculating the value inflation factors (VIF's). Moreover, we tested the autocorrelation of residuals with (Durbin-Watson test) and the normality of residuals (Kolmogorov-Smirnov test). We analysed the plot of residuals versus predicted values to check the assumptions of homoscedasticity and linearity.

Table 2. Linear regression analysis

\begin{tabular}{|c|c|c|c|c|c|c|c|c|}
\hline & \multicolumn{3}{|c|}{ Model 1 (baseline model) } & \multicolumn{5}{|c|}{ Model 2 (full model) } \\
\hline & Beta & $\mathrm{t}$ & Sig. & Beta & $\mathrm{T}$ & Sig. & Tolerance & VIF \\
\hline gender & -0.004 & -0.041 & 0.967 & 0.041 & 0.472 & 0.638 & 0.909 & 1.100 \\
\hline ESE & 0.327 & 3.747 & 0.000 & 0.306 & 3.569 & 0.001 & 0.936 & 1.069 \\
\hline Role model & -0.048 & -0.555 & 0.580 & -0.048 & -0.561 & 0.576 & 0.945 & 1.058 \\
\hline Education & -0.083 & -0.974 & 0.332 & -0.104 & -1.234 & 0.219 & 0.972 & 1.029 \\
\hline ELOC & 0.034 & 0.390 & 0.697 & 0.075 & 0.875 & 0.383 & 0.928 & 1.077 \\
\hline $\mathrm{NfC}$ & - & - & - & -0.223 & -2.552 & 0.012 & 0.899 & 1.112 \\
\hline Model & - & - & - & - & - & - & - & - \\
\hline R2 & 0.117 & - & - & 0.161 & - & - & - & - \\
\hline Adj R2 & 0.081 & - & - & 0.120 & - & - & - & - \\
\hline $\mathrm{F}$ & 3.247 & - & - & 3.913 & - & - & - & - \\
\hline Sig. of $\mathrm{F}$ & 0.009 & - & - & 0.001 & - & - & - & - \\
\hline Change in R2 & - & - & - & 0.045 & - & - & - & - \\
\hline F-Change & - & - & - & 6.514 & - & - & - & - \\
\hline Sig. of F-Change & - & - & - & 0.012 & - & - & - & - \\
\hline
\end{tabular}

Source: own calculations in SPSS.

The baseline model (Model 1 , Table 2 ) is statistically significant $(F=3.247, p<0.01$ ) and explains $8,1 \%$ of the variance of entrepreneurial intention. The full model (Model 1 , Table 2$)$ is statistically significant $(F=3.913, p<0.001)$ and explains $12 \%$ of the variance of entrepreneurial intention. In comparison with the baseline model (Model 1), its explanatory power is significantly higher ( $F$-Change is statistically significant). As evidenced by the results, need for cognitive closure has a negative and significant influence on El, and therefore, our research hypothesis is supported.

Our findings support the notion that individual cognition shapes entrepreneurial intention. Individuals that score higher on the need for cognitive closure declare lower entrepreneurial intentions. This result is in line with the career choice theory (Holland, 1997) and person-environment fit theory (Kristof, 1996), both suggesting that people are attracted to jobs that best suit their personality and needs. In this, our findings echo studies investigating the relationships between the Big Five personality traits and entrepreneurial intention (Zhao, Seibert \& Lumpkin, 2010). However, in line with the recommendations of Rauch and Frese (2007) and following Schenkel et al. (2009), instead of studying broad, general personality traits, we focus on a cognitive-motivational construct of NfC. Using a psychometrically validated measure of NfC (Kruglanski, Webster \& Klem, 1993; Jaworski, 1998) and number of control variables, we respond to calls formulated in the pioneering study by Schenkel et al. (2009). However, contrary to Schenkel et al. (2009) who find a positive correlation between NfC and nascent entrepreneurial activity, we observe a negative relationship between $\mathrm{NFC}$ and entrepreneurial intentions. Our 
results support the notion that, since both the urgency and permanence tendencies implied by NfC are not satisfied by entrepreneurial activity, people scoring high on NfC will be less inclined to pursue 'entrepreneurial' career path.

\section{CONCLUSIONS}

The objective of this paper was to shed more light on psychological antecedents of entrepreneurship, by investigating relationship between $\mathrm{NfC}$ and $\mathrm{El}$. We find that $\mathrm{NfC}$ negatively influences El, thus supporting our research hypothesis. To the best of our knowledge, this is one of the first attempt to explore the role of the need for cognitive closure in forming entrepreneurial intentions.

Our findings are tempered by a number of limitations. First, as we use a student sample, the representativeness of our results is limited. Second, we study entrepreneurial intentions and not the actual behaviour. Our findings should be now tested on larger, representative samples. Third, future studies might follow alternative conceptualisations and measurements of NfC. For example, Webster and Kruglanski (1994) originally treat $\mathrm{NfC}$ as a single latent variable. However, in line with more recent studies decisiveness may be treated as a separate factor, and studied independently from NfC. Fourth, it would be interesting to investigate the relationships between the need of cognitive closure and the actual behaviour (i.e. starting a business) and its outcomes (i.e. performance results). Fifth, we acknowledge that the predictive power of $\mathrm{NfC}$ as an antecedent of $\mathrm{El}$, as well as the predictive power of the overall regression model presented in the current study is low. This is a common limitation of studies on El (Krueger, Reilly \& Carsrud, 2000), especially those focused on a specific topic (e.g. entrepreneurial cognition) and testing a limited number of variables (Łaguna, 2006c).

In order to increase the predictive power of the model, a number of both individuallevel and contextual variables should be included. In line with the person/context interaction approach (Shaver \& Scott, 1991), there have recently been numerous calls for research combining both contextual and personal characteristics as antecedents of El (Liñán \& Fayolle, 2015). In our study we use a relatively homogeneous sample of Polish students, while controlling for context-specific variables such as previous education and family background. Further research is needed to better understand the interaction between personal-level (i.e. demographics, personality traits) and institutional-level (e.g. institutional support) variables.

Research efforts examining the antecedents of entrepreneurial intentions, including the present study, are informative to business practitioners. Following Krueger et al. (2000, p. 429), we believe that "The entrepreneurs themselves should gain considerable value from a better understanding of their own motives. The lens provided by intentions affords them the opportunity to understand why they made certain choices in their vision of the new venture".

Further research on the role of cognitive closure may bring important practical insights into entrepreneurial education and public policy. More specifically, in designing entrepreneurial education programs it is necessary to know, to which extent entrepreneurial behaviour and its outcomes can be shaped by external institutional factors. Our current research suggests that entrepreneurial intentions of Polish business students are to a large extent influenced by relatively stable, dispositional, personal-level variables, 
thus indicating potential barriers to fostering entrepreneurship through educational or institutional measures. However, further studies, incorporating both individual level and institutional level variables are needed in order to assess the impact of such measures on entrepreneurial intentions and behaviours.

\section{REFERENCES}

Ajzen, I. (1991). Theory of planned behavior. Organizational Behavior and Human Decision Processes, 50, 179-211.

Bandura, A. (1997). Self-efficacy: The exercise of control. New York: Freeman and Co.

Baron, R. (2004). The cognitive perspective: a valuable tool for answering entrepreneurship's basic "why" questions. Journal of Business Venturing, 19, 221-239.

Busenitz, L.W., \& Barney, J.B. (1997). Differences between entrepreneurs and managers in large organizations: biases and heuristics in strategic decision-making. Journal of Business Venturing, 12(1), 9-30.

Carr, J.C., \& Sequeira, J. M. (2007). Prior family business exposure as intergenerational influence and entrepreneurial intent: A Theory of Planned Behavior approach. Journal of Business Research, 60(10), 1090-1098.

Chen, C.C., Greene, P.G., \& Crick, A. (1998). Does entrepreneurial self-efficacy distinguish entrepreneurs from managers? Journal of Business Venturing, 13(4), 295-316.

Costa, P.T. Jr., \& McCrae, R.R. (1992). Revised NEO Personality Inventory (NEO-PI-R) and NEO Five Factor Inventory (NEO-FFI) professional manual. Odessa, FL: PAR.

Engle, R.L., Dimitriadi, N., Gavidia, J.V., Schlaegel, C., Delanoe, S., Alvarado, I., He, X., Buame, S., \& Wolff, B. (2010). Entrepreneurial intent: A twelve-country evaluation of Ajzen's model of planned behavior. International Journal of Entrepreneurial Behaviour and Research, 16(1), 3658.

Espíritu-Olmos, R., \& Sastre-Castillo, M.A. (2015). Personality traits versus work values: Comparing psychological theories on entrepreneurial intention. Journal of Business Research, 68(7), 15951598.

Fayolle, A., \& Liñán, F. (2014). The future of research on entrepreneurial intentions. Journal of Business Research, 67, 663-666.

Fishbein, M., \& Ajzen, I. (2010). Predicting and Changing Behavior: The Reasoned Action Approach. New York, NY: Taylor and Francis Group.

Gartner, W.B. (1988). "Who is an entrepreneur?" is the wrong question. Entrepreneurship Theory and Practice, 12(2), 47-68.

Gatewood, E., Shaver, K., \& Gartner, W. (1995). A longitudinal study of cognitive factors influencing start-up behaviors and success at venture creation. Journal of Business Venturing, 10, 371391.

Gupta, A.K., \& Govindarajan, V. (1984). Business unit strategy, managerial characteristics, and business unit effectiveness at strategy implementation. Academy of Management Journal, 27 (1), 25-41.

Gürol, Y., \& Atsan, N. (2006). Entrepreneurial characteristics amongst university students: Some insights for entrepreneurship education and training in Turkey. Education + Training, 48(1), 25-38.

Jaworski, M. (1998). Polska adaptacja Skali Potrzeby Domknięcia Poznawczego. Przeglqad Psychologiczny, 41(1-2), 151-163. 
Kaczmarek, M., \& Kaczmarek-Kurczak, P. (2012). Przegląd metaanaliz dotyczących związku cech osobowości i przedsiębiorczości. W stronę modelu badań. Management and Business Administration. Central Europe, 1(108), 49-63.

Kaczmarek, M., \& Kaczmarek-Kurczak, P. (2014). The self-efficacy (generalized as well as context specific), the big five traits and the effectiveness of the entrepreneurship education). Psychological Studies, 52(4), 39-46.

Kautonen, T., van Gelderen, M., \& Fink, M. (2015). Robustness of the Theory of Planned Behavior in Predicting Entrepreneurial Intentions and Actions. Entrepreneurship Theory and Practice, 39(3), 655-674.

Koh, H.C. (1996). Testing hypotheses of entrepreneurial characteristics: A study of Hong Kong MBA students. Journal of Managerial Psychology, 11(3), 12-25.

Kolvereid, L., \& Isaksen, E. (2006). New business start-up and subsequent entry into selfemployment. Journal of Business Venturing, 21(6), 866-885.

Kristof, A.L. (1996). Person-organization fit: An integrative review of its conceptualizations, measurement, and implications. Personnel Psychology, 49(1), 1-49.

Krueger, N.F., Reilly, M., \& Carsrud, A.L. (2000). Competing models of entrepreneurial intentions. Journal of Business Venturing, 15, 411-432.

Kruglanski, A.W. (1990). Lay epistemic theory in social-cognitive psychology. Psychological Inquiry, 1, 181-197.

Kruglanski, A.W., Webster, D.M., \& Klem, A. (1993). Motivated resistance and openness to persuasion in the presence or absence of prior information. Journal of Personality and Social Psychology, 65, 861-877.

Kruglanski, A.W., \& D.M. Webster. (1996). Motivated closing of the mind: 'Seizing' and 'freezing'. Psychological Review, 103, 263-283.

Łaguna, M. (2006a). Skala Skuteczności Przedsiębiorczej. Roczniki Psychologiczne, 9, 107-128.

Łaguna, M. (2006b). Ogólna samoocena czy przekonanie o skuteczności? Uwarunkowania gotowości do działań przedsiębiorczych u osób bezrobotnych. Przeglqad Psychologiczny, 3, 259-274.

Łaguna, M. (2006c). Nadzieja i optymizm a intencja założenia własnej firmy. Przegląd Psychologiczny, 49(4), 419-443.

Liñán, F., \& Santos, F.J. (2007). Does social capital affect entrepreneurial intentions? International Advances in Economic Research, 13(4), 443-453.

Liñán, F., \& Fayolle, A. (2015). A systematic literature review on entrepreneurial intentions : citation, thematic analyses, and research agenda. International Entrepreneurship and Management Journal, 11(4), 907-833.

Litzinger, W.D. (1965). The motel entrepreneur and the motel manager. Academy of Management Journal, 8, 268-281.

Markman, G., Balkin, D., \& Baron, R. (2002). Inventors and new venture formation: the effects of general self-efficacy and regretful thinking. Entrepreneurship Theory and Practice, 4, 149-165.

Pittaway, L., \& Cope, J. (2007). Entrepreneurship education - A systematic review of the evidence. International Small Business Journal, 25(5), 479-510.

Rauch, A., \& Frese, M. (2007). Let's put the person back into entrepreneurship research: A metaanalysis on the relationship between business owners' personality traits, business creation, and success. European Journal of Work and Organizational Psychology, 16(4), 353-385.

Reynolds, P., Hay, M., \& Camp, S.M. (1999). Global Entrepreneurship Monitor. Executive Report. Kansas City, MO: Ewing Marion Kaufmann Foundation. 
Rotter, J.B. (1966). Generalized Expectancies for Internal versus External Control of Reinforcement. Psychological Monographs, 80(1), 1-28.

Schenkel, M.T., Matthews, Ch.T., \& Ford, M.F. (2009). Making rational use of 'irrationality'? Exploring the role of need for cognitive closure in nascent entrepreneurial activity. Entrepreneurship and Regional Development: An International Journal, 21(1), 51-76.

Schlaegel, Ch., \& Koenig, M. (2014). Determinants of Entrepreneurial Intent: a meta-analytic test and integration of competing models. Entrepreneurship Theory and Practice, 38(2), 291-332.

Schumpeter, J. (1911/1960). Teoria rozwoju gospodarczego. Warszawa: PWE.

Segal, G., Borgia, D., \& Schoenfeld, J. (2005). The motivation to become an entrepreneur. International Journal of Entrepreneurial Behaviour and Research, 11(1), 42-57.

Shane, S., \& Venkataraman, S. (2000). The promise of entrepreneurship as a field of research. Academy of Management Review, 25(1), 217-226.

Shapero, A., \& Sokol, L. (1982). Social dimensions of entrepreneurship. In C.A. Kent, D.L. Sexton \& K.H. Vesper (Eds), Encyclopedia of entrepreneurship (pp. 72-90). Englewood Cliffs (NJ): Prentice Hall.

Shaver, K.G., \& Scott, L.R. (1991). Person, process, choice: The psychology of new venture creation. Entrepreneurship: Theory and Practice, 16(2), 23-45.

Teoh, H.Y., \& Foo, S.L. (1997). Moderating effects of tolerance for ambiguity and risk-taking propensity on the role conflict-perceived performance relationship: Evidence from Singaporean entrepreneurs. Journal of Business Venturing, 12(1), 67-81.

Wach, K. (2015). Środowisko biznesu rodzinnego jako stymulanta intencji przedsiębiorczych młodzieży akademickiej. Przedsiębiorczość i Zarzq̨dzanie, 16(7), 25-40.

Wainer, H.A., \& Rubin, I.M. (1969). Motivation of R\&D entrepreneurs: determinants of company success. Journal of Applied Psychology, 53(3), 178-184.

Wąsowska, A. (2016). Społeczno-poznawcze uwarunkowania intencji przedsiębiorczej. Problemy Zarzq̨dzania, 13(4), 101-114.

Webster, D.M., \& Kruglanski, A.W. (1994). Individual differences in need for cognitive closure. Journal of Personality and Social Psychology, 67(6), 1049-1062.

Wilson, F., Kickul, J., \& Marlino, D. (2007). Gender, entrepreneurial self-efficacy, and entrepreneurial career intentions: Implications for entrepreneurship education. Entrepreneurship: Theory and Practice, 31(3), 387-406.

Zhao, H., \& Seibert, S.E. (2006). The Big Five personality dimensions and entrepreneurial status: A meta-analytical review. Journal of Applied Psychology, 91(2), 259-271.

Zhao, H., Seibert, S.E., \& Lumpkin, G.T. (2010). The Relationship of Personality to Entrepreneurial Intentions and Performance: A Meta-Analytic Review. Journal of Management, 36(2), 381404. 


\title{
Author
}

\begin{abstract}
Aleksandra Wąsowska
Assistant Professor in the Department of Strategic and International Management at the Faculty of Management, the University of Warsaw (UW). She received master degrees in Management (UW), Iberian Studies (UW) and Psychology (SWPS University). She gained business experience in multinational companies (Ernst \& Young, BNP Paribas). So far she has published in journals such as European Journal of International Management or Journal for East European Management Studies. She is the author of chapters in books published by internationally recognized publishers such as Palgrave Macmillan, Edward Elgar, Wiley. Her scientific interests include decision-making processes in international corporations, internationalization strategies of companies from emerging markets and the psychological antecedents of international entrepreneurship.
\end{abstract}

Correspondence to: Dr Aleksandra Wąsowska; University of Warsaw; Faculty of Management; ul. Szturmowa 1/3; 02-678 Warsaw, Poland; e-mail: awasowska@wz.uw.edu.pl

\section{Copyright and License}

This article is published under the terms of the Creative Commons Attribution - NonCommercial - NoDerivs (CC BY-NC-ND 3.0) License http://creativecommons.org/licenses/by-nc-nd/3.0/ 
